\title{
Spatiotemporally Differential Expression of HER (Human Epithelial Growth Factor Receptor)-2 with Sexual Dimorphism in Submandibular Gland of Mice
}

\author{
Expresión Espacialmente Diferencial de HER (Receptor del Factor de Crecimiento \\ Epitelial Humano) -2 con Dimorfismo Sexual en la Glándula Submandibular de Ratones
}

\author{
Atthapon Pidsaya ${ }^{1}$; Wiphawi Hipkaeo ${ }^{1,3}$; Hisatake Kondo $^{2}$ \& Kajee Pilakasiri $^{3}$
}

PIDSAYA, A.; HIPKAEO, W.; KONDO, H. \& PILAKASIRI, K. Spatiotemporally differential expression of HER (human epithelial growth factor receptor)-2 with sexual dimorphism in submandibular gland of mice. Int. J. Morphol., 39(5):1302-1310, 2021.

SUMMARY: Considering that the submandibular gland (SMG) of postnatal mice performs active cell proliferation, apoptosis and differentiation which are regulated by proto-oncogene products in cancerous cells, the expression and localization of a proto-oncogene product HER (human epidermal growth factor receptor)-2 was examined in SMG of postnatal mice. In Western blot analysis, the expression for HER-2 was high until pre-puberty, and it decreased from puberty to young adult stages with male SMG more dominant. In immunohistochemistry, the immunoreactivity was positive in acinar and ductal cells of newborn SMG with distinct localization at the intercellular apposition sites. The immunoreactivity in acinar cells progressively decreased to negligible levels by pre-pubertal stage, while it remained positive in most ductal cells throughout the postnatal time-course. The immunoreactivity in cells of terminal tubules and intercalated ducts, both of which have a high potential to produce cells, were seen at levels similar to those of more proximal ducts, while the immunoreactivity in ductal basal cells was significantly high, but the granular convoluted tubule cells were seen at negligible levels in male and at faint levels in female. In immuno-electron microscopy of excretory ducts, the immunoreactivity was dominantly localized on the basal infolding membranes as well as vesicles and vacuoles of various sizes, but rarely in Golgi apparatus and mitochondria. The immunoreactivity without association to any membranous structures were also seen, though not numerous. The relation of expression levels of HER-2 in various portions of normal SMG to those in their cancerous ones is briefly discussed.

KEY WORDS: HER-2; Submandibular gland; Testosterone; Mice; Postnatal development.

\section{INTRODUCTION}

The major salivary glands of mice provide an excellent model for studying the cell proliferation, differentiation and apoptosis, leading to the organogenesis, because they continue postnatal extensive development of its acinar and ductal cells under the control of neuronal and hormonal mechanisms (Gresik, 1980; Hipkaeo et al., 2004). Briefly stating, the epithelial component of the gland at birth consists of rudimental acini termed the terminal tubules (TT) composed of TT cells, and immature ducts. Until puberty at about postnatal 4 week $(\mathrm{P} 4 \mathrm{~W})$, the TT cells undergo active proliferation and may differentiate into acinar cells and/or into intercalated duct (ID) cells, while remainders of immature ducts are differentiated into striated ducts (SD) and excretory ducts (ED). In the submandibular gland (SMG), SD cells further differentiate into granular convoluted tubule (GCT) cells containing characteristic secretory granules at and after puberty. The differentiation into GCT cells are more prominent in males than in females by influence of testosterone and some other endocrine hormones (Gresik, 1980; Hipkaeo et al.). There has further been evidence suggesting that apoptosis contributes to the maintenance of well-organized branching of the glandular tubular system, and it may also contribute to the development of autoimmune exocrinopathy including Sjögren's syndrome in the salivary glands of estrogen-deficient mice (Arakaki et al., 2010).

It is known that the cell proliferation, differentiation and apoptosis are regulated by proto-oncogene products in cancerous cells as well as normal ones, and alterations in the cellular activities result in tumorigenesis (Amsterdam

\footnotetext{
${ }^{1}$ Electron Microscopy Unit, Department of Anatomy, Faculty of Medicine, Khon Kaen University, Khon Kaen Thailand.

${ }^{2}$ Department of Anatomy Tohoku University, Sendai, Japan.

${ }^{3}$ Department of Anatomy, Faculty of Medicine Siriraj Hospital, Mahidol University, Bangkoknoi, Bangkok, Thailand.
} 
\& Selvaraj, 1997; Lewis-Wambi \& Jordan, 2009). In this regard, HER-2, a member of the human epidermal growth factor receptor (EGFR) family, should be noted. While its gene is amplified and over expressed in a wide range of adenocarcinomas including those of salivary glands as well as breast mammary glands (Slamon et al., 1987; Liang et al., 2018), increased expression of HER-2 promotes cell proliferation and extend cell survival by blocking apoptosis in non-cancerous cells (Gilhus et al., 1995). There have been, however, relatively few studies on the expression of HER-2 in normal salivary glands, in which its weak expression have briefly been described to occur in ductal cells of adult humans and positive expression in acini of human fetal glands (Quirke et al., 1989; Press et al., 1990).

Considering the information described above and the idea that knowledge of the normal tissue distribution of a given proto-oncogene product may shed light on the function of the protein, the present study was attempted to examine the expression and localization of a protooncogene HER-2 in the submandibular gland of normal mice at various stages of postnatal development in immunoblotting and immuno-light and electron microscopy.

\section{MATERIAL AND METHOD}

Animals and tissues preparation. ICR mice of both sexes were used in the present study. Three mice of each sex were sacrificed at each of six time points: postnatal $1^{\text {st }}$ day (POW), $1^{\text {st }}$ week (P1W), P2W, P4W, P6W and P8W. For testosterone treatment, 15 female mice at $\mathrm{P} 6 \mathrm{~W}$ were divided into five groups. Mice of the four groups, three each, were subjected to a daily subcutaneous injection of testosterone (Panreac Applichem, Ottoweg, Germany, $25 \mathrm{mg} / \mathrm{kg}$ body weight) dissolved in $0.1 \mathrm{~mL}$ of olive oil. Mice of the individual groups were sacrificed at $24^{\text {th }}, 48^{\text {th }}, 72^{\text {th }}$ and $96^{\text {th }}$ hours after the first injection. Remaining 3 mice were subjected to a daily injection of vehicle alone $(0.1 \mathrm{~mL}$ of olive oil) for 4 days, and they were sacrifice done by one at the same intervals of days as described above.

All experiments were conducted in accordance with Guidelines for the Care and Use of Laboratory Animals at Khon Kaen University and approved by the Animal Ethics Committee of Khon Kaen University, based on the Ethical Principles and Guidelines for the Use of Animals: National Research Council of Thailand with the ethics number IACUCKKU-103/62.

Immunoblotting analysis. Mice at the various postnatal and post-injection stages were sacrificed by deep anesthesia with sodium pentobarbital (Cat \# 76744, Merck; KgaA, Germany; $60 \mathrm{mg} / \mathrm{kg}$ bodyweight) and subsequently SMGs at the right side were extirpated after ligation of blood vessels relating to them under stereo-microscope, and frozen at $-80^{\circ} \mathrm{C}$ until use. The frozen glands were homogenized in a lysis buffer containing the proteinase inhibitor cocktail (Roche; Mannheim, Germany). The lysates were centrifuged at12,000 rpm. The supernatants were collected and measured for the protein concentration. The proteins of $40 \mathrm{mg}$ in total from each lysate were boiled for 10 min in 2x SDS (sodium dodecyl sulfate) sample buffer and subjected to SDS/10 \% PAGE (polyacrylamide gel electrophoresis). They were then blotted to a PVDF (polyvinylidene difluoride) membrane (GE Healthcare; Buckinghamshire, UK). After blocking nonspecific binding sites with $5 \%$ skim milk (wt/vol)/TBS (Trisbuffered saline) $/ 0.3 \%$ tween- 20 , the membranes were incubated overnight at $4{ }^{\circ} \mathrm{C}$ with a rabbit monoclonal antibody against HER-2 (\#2165, Cell Signaling Technology, Massachusetts, USA; $0.1 \mathrm{mg} / \mathrm{ml}$ ) in $5 \%$ skim milk (wt/vol)/ TBS/0.1\% tween-20. The membranes were then treated with mouse peroxidase-conjugated anti-rabbit $\operatorname{IgG}$ (dilution 1: 2500 ) for $1 \mathrm{~h}$ at room temperature. Goat polyclonal antibody against b-actin was used as the internal control. Student's ttest of statistical analysis was used to analyze the difference between two mean values. The post hoc tests in the ANOVA was used to analyze the difference among multiple mean values, and resulting P-value less than 0.05 was regarded as the significant difference.

Immuno-light microscopy. Mice at the various postnatal and post-injection stages, soon after the right side SMGs were extirpated, were perfused through the heart with $10 \mathrm{ml}$ physiological saline, followed by $10 \mathrm{ml}$ of $4 \%$ paraformaldehyde in $0.1 \mathrm{M}$ phosphate buffer. The SMGs at the left side were removed and postfixed with the same fixative for overnight. Specimens were dipped into $30 \%$ sucrose/PB for cryo-protection. Sections of $20 \mu \mathrm{m}$ thickness were made on a cryostat and mounted on glass slides. After incubation for 10 min with $0.3 \% \mathrm{H}_{2} \mathrm{O}_{2}$ /methanol to inhibit intrinsic peroxidase activity, the sections on glass slides were further incubated for 30 min with $10 \%$ normal goat serum in phosphate buffer saline to prevent non-specific binding of the antibody. They were then incubated at room temperature overnight with the rabbit IgG against HER-2 (1 $\mathrm{mg} / \mathrm{ml}$ ), and subsequently with biotinylated goat anti-rabbit $\operatorname{IgG}(\mathrm{H}+\mathrm{L})$ (Abcam; Cambridge, MA USA) for $1 \mathrm{~h}$ at room temperature. The antigen-antibody reaction sites were visualized using diaminobenzidine reaction with an $\mathrm{ABC}$ kit (Vector Laboratories; Burlingame, CA, USA).

Immuno-gold electron microscopy. Cryostat-sections of P4W female SMGs were mounted on plastic slides precoated with $0.1 \%$ poly-L-lysine. After blocking nonspecific 
reactions by $5 \%$ bovine serum albumin and overnight incubation with the primary antibody $(5 \mathrm{mg} / \mathrm{ml})$, the sections were reacted with goat anti-rabbit $\operatorname{IgG}$ covalently conjugated with ultra small gold particles (1:100 in dilution) (Nanoprobes; Yaphank, NY, USA). Following treatment with a silver enhancement kit (Aurion; Hatfield, PA, USA), the sections were then post fixed with $1 \%$ osmium tetroxide, dehydrated, embedded in Epon, and polymerized in $60{ }^{\circ} \mathrm{C}$ oven for $48 \mathrm{~h}$. Ultrathin sections were prepared and mounted on single-hole grids covered with formvarfilms. The sections were then stained with uranyl acetate and lead citrate for observation and analysis in electron microscopy.

\section{RESULTS}

Immunoblot analysis. A single band with a size of $185 \mathrm{kDa}$ was clearly seen in homogenates of SMGs of normal mice of both sexes throughout the postnatal development with the highest density at P0W and P2Wand decreasing densities thereafter, and with a higher density in female than male glands at P4W-P8W (Figs. 1A, B).

In homogenates of SMG of female mice with a daily testosterone-injection (TI) started at P6W, the relative density of immunoblot band for HER-2 showed a temporary and significant rise at TI day 1 and 2, a level similar to that of the pre-injection stage at TI day 3 , and a significant decrease at TI day 4 down to that of the male counterpart at P6W $(P<0.05)$ (Figs. $1 C, D)$. No significant differences in the density of blot bands were discerned between SMGs from female mice with the vehicle-injection for 4 days and those without injection at P6W (data not shown).

HER2

\section{$\beta$-actin}

A

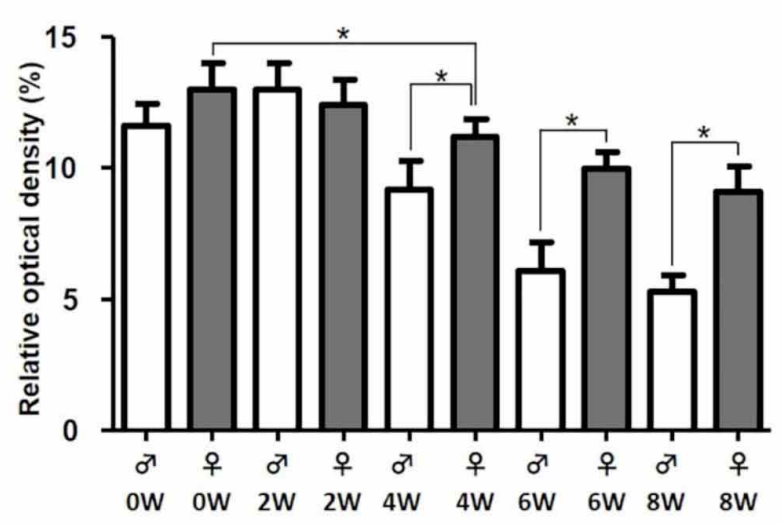

B

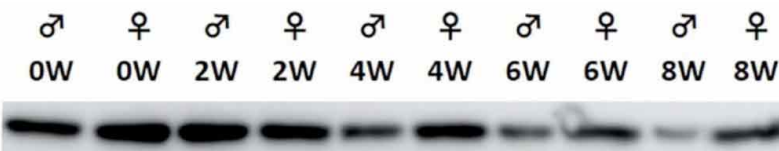

$42 \mathrm{kDa}$
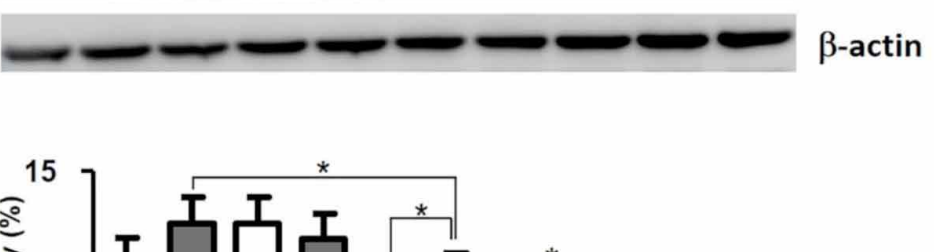

\section{(1)}


Immuno-light microscopy. In SMGs of mice of both sexes at P0W, HER-2-immunoreactivity was weak and diffuse in the cytoplasm of almost all gland cells forming immature acini and ducts, and it was also seen as weak to moderate in forms of lines along the intercellular apposition sites of the epithelia in immature acini and ducts (Fig. 2A). In SMGs of both sexes at $\mathrm{P} 1 \mathrm{~W}$, the immunoreactivity remained weak and diffuse in epithelial cells of almost all ducts and some

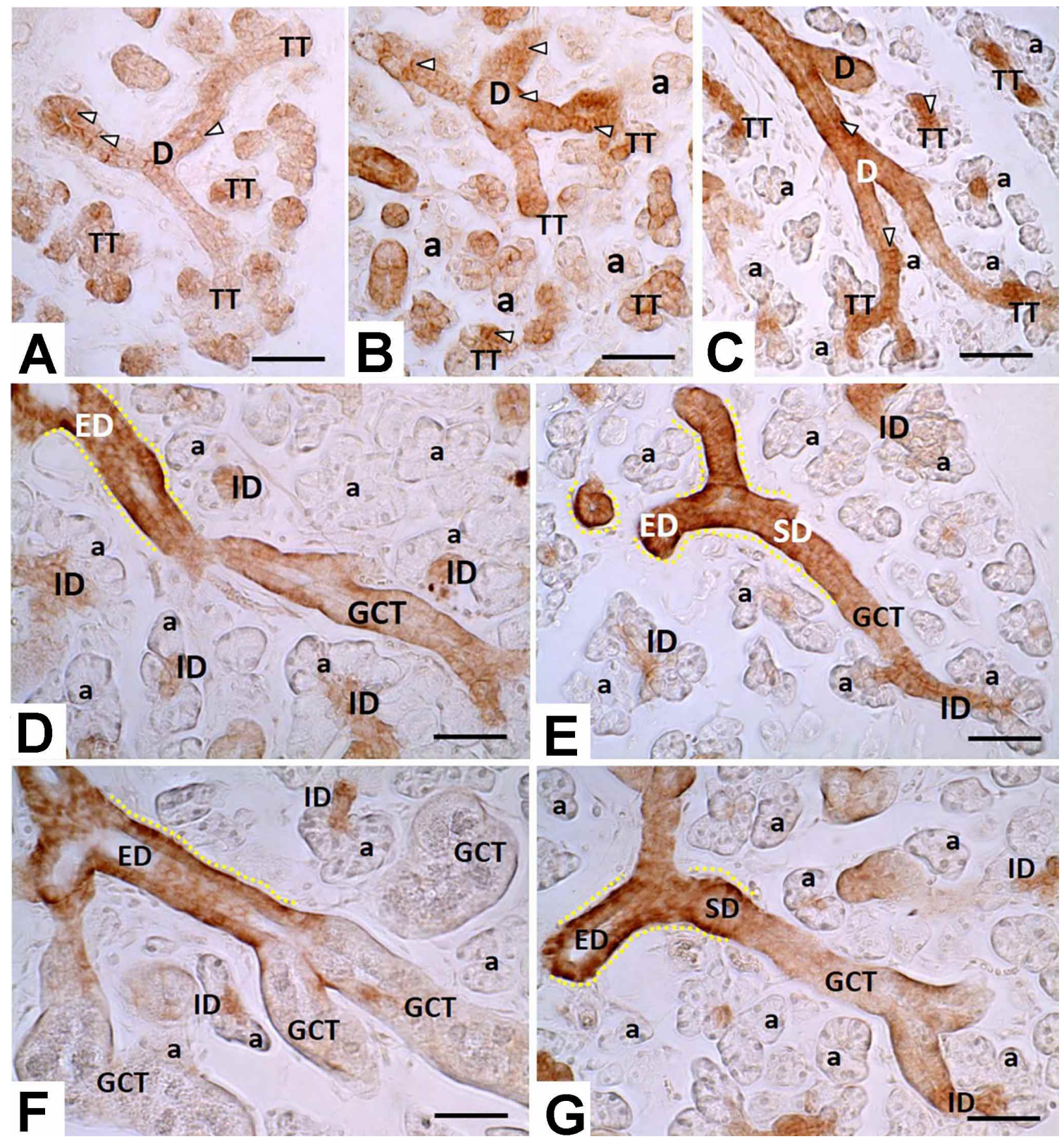

Fig. 2. Immuno-DAB light micrographs for HER-2 of SMGs at P0W ( $2 \mathrm{G}$ male), P1W ( $2 \mathrm{G}$ male), $\mathrm{P} 2 \mathrm{~W}$ ( $2 \mathrm{C}$ male), $\mathrm{P} 4 \mathrm{~W}$ (2D male, 2E female), and P8W (2F male; $2 \mathrm{G}$ female). Note HER-2-immunoreactivity in almost all terminal tubules (TT) and ductal (D) cells at P0W with its distinct line-form appearance at intercellular apposition sites, the immunoreactivity at P1W higher in ducts, terminal tubules and similar to, or lower in new differentiated acini (a), and that at P2W in ducts similar to P1W in contrast to no significant immunoreactivity in acini. Also note the immunoreactivity in terminal tubules (TT) and intercalated ducts (ID) at levels slightly higher than or similar to that in remaining portions of ducts at POW$\mathrm{P} 2 \mathrm{~W}$. At P4W, faint immunoreactivity in differentiating granular convoluted tubules (GCT) with much lower levels in male, in contrast to remaining immunoreactivity in striated and excretory ducts (SD, ED) with distinct appearance at intercellular apposition sites and cell base domains (dot lines in $\mu \mathrm{m}$ ) in both sexes. At P8W, attenuated immunoreactivity throughout entire gland including SD and ED with that in male glands remarkable. Arrowheads: intercellular apposition sites. Bars represent $50 \mu \mathrm{m}$. 
PIDSAYA, A.; HIPKAEO, W.; KONDO, H. \& PILAKASIRI, K. Spatiotemporally differential expression of HER (human epithelial growth factor receptor)-2 with sexual dimorphism in submandibular gland of mice. Int. J. Morphol., 39(5):1302-1310, 2021.

acini, in which it was moderate at the intercellular appositions in forms of lines. In some other acinar cells, however, the immunoreactivity was at almost negligible levels and no immunoreactivity was discerned at the intercellular apposition sites. Some, but not all, terminal tubules (TT), which were distally continuous to immature acini, exhibited slightly higher immunoreactivity than more proximal ducts, and distinctly immunoreactive intercellular apposition (Figs. 2B, 3A). In addition, moderate immunoreactivity was also found along the bases of some epithelial cells in thicker and more proximal portions of immature ducts.

In SMGs of both sexes at P2W, although the immunoreactivity appeared basically in a pattern similar to that at P1W in ductal and acinar cells including TT cells, some ductal cells of striated ducts (SD) slightly decreased in the immunoreactivity. Different from the previous stages, were the appearance of almost all acinar cells free of the immunoreaction and the absence of immunoreactivity at the intercellular apposition in the acini (Fig. 2C). No significant differences were found in the immunoreactivity patterns including the relative intensities of gland cells between male and female specimens at $\mathrm{P} 0-2 \mathrm{~W}$.

At P4W when the granular convoluted tubules (GCT) start to differentiate with a more dominant extent in male (Gresik, 1980), HER-2-immunoreactivity was negligible within the entire cytoplasm of male GCTcells except for their cell bases remaining faint reaction, while it was discerned, though weaker than that at $\mathrm{P} 2 \mathrm{~W}$, within the cytoplasm of female GCT cells including the cell bases (Figs. 2D, E). Weak immunoreactivity for HER-2was discerned diffusely in intercalated duct (ID) cells, while it was moderate and diffuse within the cytoplasm of SD cells and excretory ductal (ED) cells in both male (Fig. 2D) and female (Fig. 2E) SMGs. In SD and ED cells, the immunoreactivity was distinct at the intercellular apposition sites. In addition, intense immunoreactivity for HER-2 was confined to basal cells of the ducts. No significant immunoreactivity was seen in any acini of both male and female SMG.

At P8W, male GCT cells were almost free of the immunoreaction, while female GCT cells were weakly immunoreactive at their bases. The immunoreactivity in SD and ED cells appeared basically in the same intracellular pattern as that at $\mathrm{P} 4 \mathrm{~W}$, with distinct immunoreactivity in their basal cells in SMG of both sexes. The immunoreactivity in ID was weak in SMG of both sexes (Figs. 2F, G and 3B).

In $\mathrm{SMG}$ of female mice on $4^{\text {th }}$ day after a daily injection of testosterone (TI $96 \mathrm{~h}$ ), GCT was free of the immunoreaction, in contrast to the remaining faint immunoreaction at P8W, while the SD and ED were almost similar to those of female SMG at P8W (data not shown).

In control experiments omitting the primary antibody, no immunoreactions were seen in any portions of SMG sections of mice of either sex at P4W (data not shown).

Immuno-electron microscopy. Based on immuno-light microscopic findings described above, ultrastructural analysis was focused on SD of P4W female mice, with attention to the higher immunoreactivity in a wider variety of cell species than any other postnatal stages and male specimens.

Gold particles representing HER-2-immunoreactivity were deposited densely along the plasma membranes of basal infoldings in the infranuclear portion of columnar epithelial cells of SD. No significant labelings of gold particles were found on mitochondria or in the basal cells of ED. In the supranuclear portion of the immunoreactive cells, gold particles were seen rather sparsely along apposed plasma membranes of two adjacent epithelial cells. Gold particles were deposited in intimate relation with some small vesicles scattered throughout the cytoplasm, while they were not found in intimate relation to Golgi apparatus and nuclear
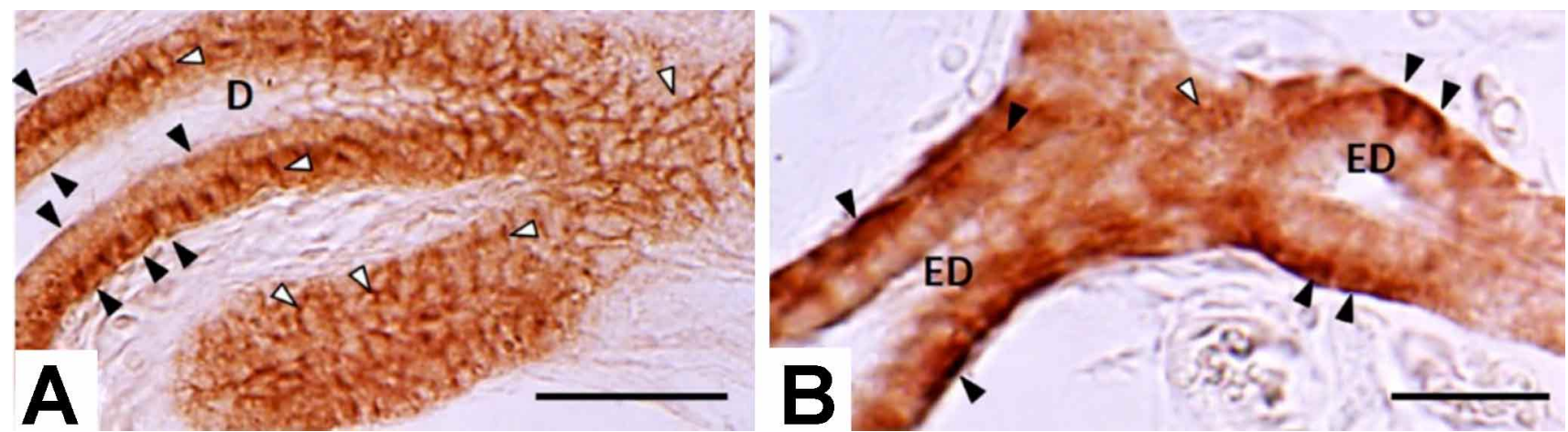

Fig. 3. Immuno-DAB light micrographs for HER-2 at higher magnification of male ducts of SMGs at P1W (3A) and P8W (3B). Note the distinct appearance at intercellular apposition sites (white arrowheads) and cell base domains (black arrowheads) in the duct (D) at P1W and in excretory ducts (ED) at P8W. Bars represent $50 \mu \mathrm{m}(3 \mathrm{~A})$, and $25 \mu \mathrm{m}(3 \mathrm{~B})$. 
membranes. A majority of mitochondria were free of goldlabeling. In addition, some gold particles without relation to any vesicle membranes were randomly seen in the cytoplasm (Figs. 4A-C).
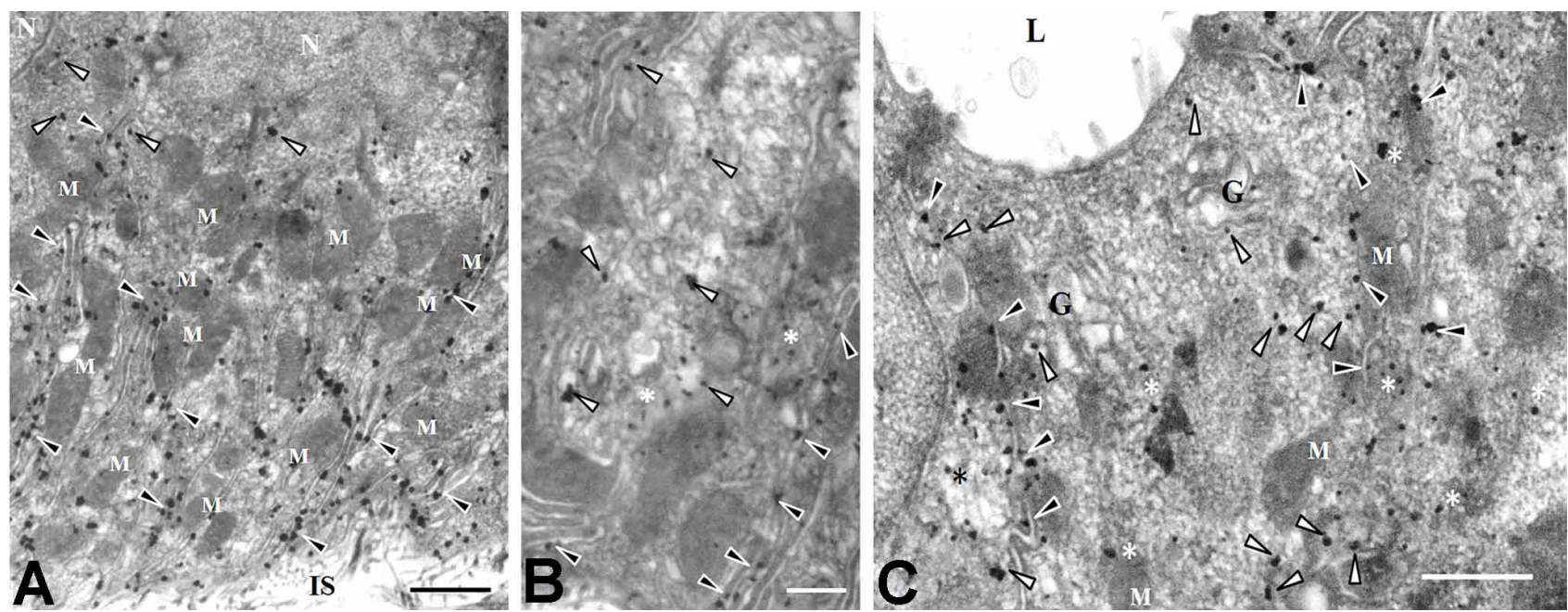

Fig. 4. Immuno-gold electron micrographs for HER-2 in female striated ductal cells at P4W. Note dense deposits of immuno-gold particles (black arrowheads) along the basal infolding membranes. Also note immuno-gold particles on vesicles of various sizes dispersed in the cytoplasm (white arrowheads). Some gold particles without clear association to vesicles are noticed randomly (*). No significant occurrence of gold particles on apical plasma membranes, Golgi apparatus (G) and most mitochondria (M). IS: interstitial spaces, L: gland lumen, N: nucleus. Bars represent $600 \mathrm{~nm}$ (4A), $300 \mathrm{~nm}$ (4B), $500 \mathrm{~nm}$ (4C).

\section{DISCUSSION}

A main finding to be first noted in the present study is a spatio-temporal variety in the expression for HER-2 in mouse SMG during the postnatal development. The occurrence of HER-2-immunoreactivity within acinar cells including their intercellular apposition was confined to the stages of $\mathrm{P} 0 \mathrm{~W}$ and $\mathrm{P} 1 \mathrm{~W}$, in contrast to its sustained expression and localization in ductal cells except for GCT cells until the young adult stage of mice. Of the immature ducts, the TT cells and ID cells were expected, before the start of this study, to express/localize distinct immunoreactivity for HER-2, considering the fact that TT cells actively proliferate and differentiate into acinar cells as well as ID cells which keep a potential of proliferation (Gresik, 1980). However, their immunoreaction-intensity was generally not distinctly high from that of remaining ducts continuous to them. Such ID cells remained weak immunoreactivity throughout the postnatal development. In contrast, relatively high immunoreactivity for HER-2 was maintained in SD and ED, in which the basal cells exhibited distinct immunoreactivity. The latter cells are considered to be potential for mitosis to renew superficial cells similar to the general stratified epithelium (Rawangwong et al., 2020). As being compatible with the present finding, a previous study has reported the occurrence of HER-2 immunoreactivity in the basal cells of normal skin of adult rats (Kokai et al., 1987).
Regarding the spatio-temporally heterogenous expression in different portions of the duct system, previous studies on human salivary gland tumors have reported that tumors originating from ED show higher rates of HER-2 overexpression, resulting in higher malignancy, than tumors originating from ID (Glisson et al., 2004; Can et al., 2018). About normal human salivary gland, only one study is available and briefly reported the occurrence of HER-2immunoreactivity in normal salivary glands, in which the expression was shown to be higher in fetal human glands than corresponding adult glands without clear differential description of acini and ducts (Press et al.). The higher expression at fetal stages than at adult stages has also been shown in several tissues such as kidney, lung, nervous system and connective tissues (Coussens et al., 1985; Kokai et al.). Because of absence of information on HER-2 localization in the human gland at levels of details corresponding to that on mice in the present study, it is too mature to make any interpretation on the significance of the difference in malignancy extent between tumors derived from the two different portions of the ductal system. If, however, the present data on mice will be verified later to be the case inhuman glands, the immuno-intensity levels in normal specimens may give us a substantial speculation on its malignancy when a given cell is cancerous in the gland. 
PIDSAYA, A.; HIPKAEO, W.; KONDO, H. \& PILAKASIRI, K. Spatiotemporally differential expression of HER (human epithelial growth factor receptor)-2 with sexual dimorphism in submandibular gland of mice. Int. J. Morphol., 39(5):1302-1310, 2021.

Another issue to be noted in the present study is the cytoplasmic/cytosolic versus membranous localization of HER-2-immunoreactivity, in spite that HER-2 is a transmembrane protein judging from its molecular structure (Slamon et al.). There have so far been a substantial number of studies noting the "cytoplasmic"HER-2-localization in various carcinomas (Zschiesche et al., 1994; Kapitanovic et al., 1997; Half et al., 2004; Faratian et al., 2009), and there has been associated controversy about whether "cytoplasmic/ cytosolic" staining represents an immunohistochemical artifact. The term "cytoplasmic/cytosolic" in this kind of controversy has been largely based on the diffuse appearance of HER-2 immunoreactivity in cells examined in immunelight microscopy, in addition to the immunoreactivity on the intercellular apposition sites in forms of lines. The latter appearance is, needless to say, easily understood as representing its membranous localization. Two types of ultrastructural localization have been clarified for a given molecule which shows the diffuse intracellular localization in immuno-light microscopy: The one is its localization on tiny vesicles dispersed throughout the cells in single ultrathin sections. In view of the difference of several hundred times in the thickness between sections employed in light microscopy $(<20 \mu \mathrm{m})$ and electron microscopy $(<0.1 \mu \mathrm{m})$, it is possible to understand that such dispersed immunoreactive vesicles in single ultrathin sections, after superimposition hundred times, correspond to the diffuse appearance of its immunoreactivity throughout the cells in light microscopy. This is exemplified by our recent study on the localization of a receptor (Kamnate etal., 2021) and by some others. The other is its localization, especially by immuno-golds, without relation to any organelles in the cytoplasm in singleultrathin sections. This feature, however, is actually not easy to be correctly interpreted because of the "ultrathin" section in which the immunoreaction, even if not associated with any vesicles in a single ultrathin section, is still possible to be associated with vesicles in another ultrathin section next to that showing no such association. It is also because of rather compact aggregations of organelles in cells and infrequent appearance of cytoplasmic matrices sufficiently spacious for immuno-golds to occupy freely. Strictly saying, the cytoplasmic matrix in ultrastructure is defined as structure-less spaces among organelles, and it is customarily regarded as equivalent to the cytosolic or cytoplasmic in the biochemical terminology which is defined as the most centrifugal fraction in the centrifuge after centrifugation of cell homogenates at a speed of 105,000 rpm, and as the fraction released out of living cells treated with detergents (Schliwa et al., 1981).

Taken all together, a question on whether a given molecule is cytoplasmic/cytosolic or membranous should be resolved primarily by biochemical cell fractionation analyses, and the electron microscopy solely plays a supportive role for the biochemical interpretation. In this regard, the detection of HER-2 immuno reaction in immunoblots of both the membrane and cytosolic fractions of some colorectal cancer cell lines has been reported in previous studies by others (Chavany et al., 1996; Half et $a l$.). Considering the result in the cell fractionation studies, together with the present immune-electron microscopic finding that some immuno-gold particles wereseen without specific association with vesicles and the present diffuse "cytoplasmic" light microscopic image of almost all ductal cells except for GCT cells, it is reasonable to conclude that HER-2 is both membranous and cytoplasmic/cytosolic in normal gland cells and various cancerous cells, in which HER-2 has been reported to occur by previous authors. In order to compromise this interpretation with the known fact that HER-2 contains a transmembrane protein in its molecular sequence, it is necessary to examine whether or not HER-2 has an isoform with a molecular size similar to the original one but without a transmembrane-domain. The possible presence of such an isoform of HER-2 may explain an association of "cytoplasmic" HER-2immunoreactivity with better differentiation in some cells, and a higher level of HER-2 mRNA levels in tumor cells with membrane staining than those with "cytoplasmic" one in gastric, colorectal and renal cell carcinomas (Oshima et al., 2001; Half et al.).

Regarding the functional exertion of HER-2 localized on the vesicular membranes, a rather conventional way which is already known as the membrane trafficking in general cell biology (Herrmann \& Spang, 2015) is highly likely, that is, membrane proteins including HER-2 is synthesized and integrated in the vesicular membranes and traverses the cytoplasm toward the plasma membranes by the membrane transport.

The other main finding from the present study is the gradual decrease of HER-2 expression during normal postpuberty (after $\mathrm{P} 4 \mathrm{~W}$ ) developmental processes with a more remarkable decrease in male as shown in the present immuno-blot of SMG.This decrease was revealed in immunohistochemistry to be ascribed to the relative increase in volume of GCT cells immunonegative for HER-2 to the total gland. It is known that, from around $\mathrm{P} 4 \mathrm{~W}$ of mice, the differentiation of GCT cells from SD cells is active, especially remarkable in male SMG, under the control of hormonal factors such as androgens as stated in Introduction (Gresik, 1994; Hipkaeo et al.). It is thus likely that the higher decrease in expression levels of HER-2in male SMG than female counterpart is ascribed to a more remarkable differentiation of the immunonegative GCT owing to a dominantly increased activity of intrinsic testosterone in 
male. As a supportive evidence for this interpretation, we found a further decrease in the immunoblot band density in female SMG on day 4 of the daily testosterone injection (TI 96h) starting at P6W, reaching down to the expression level similar to that of male counterparts. However, the present extrinsic testosterone administration showed a transient increase in HER-2 expression in SMG before its eventual attenuation by immunoblots. Regarding the interpretation of this finding, a previous study by one (WH) of the present authors should be noted (Hipkaeo et al.). According to their study, a transient rise in immunoblot-reactivity for JunD, a proto-oncogeneproduct and a transcription factor, was found in SMG at TI day1 of young adult mice and the immunoblotreactivity returned to the pre-injection level at TI day 2 . Based on the immunoblot finding together with an immunohistochemical evidence for differentiation of JunDimmunopositive SD cells into immunonegative GCT cells by TI, they concluded JunD to be involved in the testosterone-dependent differentiation of SD cells into GCT. From the similar time-course of the response to the extrinsic administration of testosterone, although the present immunohistochemistry failed in clear detection of transient and significant increase in HER-2 immunoreactivity in SMG including SD compatible with the finding in Western blot, it is possible to speculate that the transient increase of HER2expression in response to the present extrinsically administrated testosterone represents a somehow involvement of HER-2 in the differentiation of SD-cells into GCT cells like JunD. Further examination at the molecular level is necessary to see whether or not HER-2 can interact with testosterone and how HER-2 is involved in the differentiation of SD cells into GCT under such a supernormal testosterone condition.

ACKNOWLEDGEMENTS. The authors would like to thank Mr. Hipkaeo D. and Ms Polsan Y, Electron Microscopy Unit, Department of Anatomy, Faculty of Medicine, KKU, for technical supports.

PIDSAYA, A.; HIPKAEO, W.; KONDO, H. \& PILAKASIRI, K. Expresión espacialmente diferencial de HER (receptor del factor de crecimiento epitelial humano)-2 con dimorfismo sexual en la glándula submandibular de ratones. Int. J. Morphol., 39(5):13021310, 2021.

RESUMEN: Considerando que la glándula submandibular (GSM) de ratones postnatales realiza la proliferación celular activa, apoptosis y diferenciación que están reguladas por productos protooncogénicos en células cancerosas, la expresión y localización de un producto protooncogénico HER (receptor del factor de crecimiento epidérmico humano) - 2 se examinó en GSM de estos ratones. En el análisis de Western blot, la expresión de HER-2 fue alta hasta la prepubertad, y disminuyó desde la pubertad hasta las etapas de adultos jóvenes con GSM macho más dominante. En inmunohistoquímica, la inmunorreactividad fue positiva en las células acinares y ductales de GSM de recién nacido con una localización distinta en los sitios de aposición intercelular. La inmunorreactividad en las células acinares disminuyó progresivamente a niveles insignificantes en la etapa prepuberal, mientras que permaneció positiva en la mayoría de las células ductales durante el transcurso del tiempo posnatal. La inmunorreactividad en las células de los túbulos terminales y los conductos intercalados, los cuales tienen un alto potencial para producir células, se observó a niveles similares a los de los conductos más proximales, mientras que la inmunorreactividad en las células basales ductales fue significativamente alta, pero en el túbulo contorneado granular las células se observaron en niveles insignificantes en los machos y en niveles débiles en las hembras. En la microscopía inmunoelectrónica de los conductos excretores, la inmunorreactividad se localizó de manera predominante en las membranas de pliegues basales, así como en vesículas y vacuolas de varios tamaños, pero raramente en el aparato de Golgi y en las mitocondrias. También se observó la inmunorreactividad sin asociación a ninguna estructura membranosa, aunque no numerosa. Se discute brevemente la relación de los niveles de expresión de HER-2 en varias porciones de GSM normal con aquellos en sus cancerosos.

PALABRAS CLAVE: HER-2, glándula submandibular, Testosterona; Ratones; Desarrollo posnatal.

\section{REFERENCES}

Amsterdam, A. \& Selvaraj, N. Control of differentiation, transformation, and apoptosis in granulosa cells by oncogenes, oncoviruses, and tumor suppressor genes. Endocr. Rev., 18(4):435-61, 1997.

Arakaki, R.; Ishimaru, N. \& Hayashi, Y. Immunotherapeutic targets in estrogen deficiency-dependent Sjögren's syndrome-related manifestations. Immunotherapy, 2(3):339-46, 2010.

Can, N. T.; Lingen, M. W.; Mashek, H.; McElherne, J.; Briese, R.; Fitzpatrick, C.; van Zante, A. \& Cipriani, N. A. Expression of hormone receptors and HER-2 in benign and malignant salivary gland tumors. Head Neck Pathol., 12(1):95-104, 2018.

Chavany, C.; Mimnaugh, E.; Miller, P.; Bitton, R.; Nguyen, P.; Trepel, J.; Whitesell, L.; Schnur, R.; Moyer, J. \& Neckers, L. p185erbB2 binds to GRP94 in vivo. Dissociation of the p185erbB2/GRP94 heterocomplex by benzoquinone ansamycins precedes depletion of p185erbB2. J. Biol. Chem., 271(9):4974-7, 1996.

Coussens, L.; Yang-Feng, T. L.; Liao, Y. C.; Chen, E.; Gray, A.; McGrath, J.; Seeburg, P. H.; Libermann, T. A.; Schlessinger, J.; Francke, U.; et al. Tyrosine kinase receptor with extensive homology to EGF receptor shares chromosomal location with neu oncogene. Science, 230(4730):1132-9, 1985.

Faratian, D.; Munro, A.; Twelves, C. \& Bartlett, J. M. S. Membranous and cytoplasmic staining of $\mathrm{Ki} 67$ is associated with HER2 and ER status in invasive breast carcinoma. Histopathology, 54(2):254-7, 2009.

Gilhus, N. E.; Jones, M.; Turley, H.; Gatter, K. C.; Nagvekar, N.; NewsomDavis, J. \& Willcox, N. Oncogene proteins and proliferation antigens inthymomas: increased expression of epidermalgrowth factor receptor and Ki67 antigen. J. Clin. Pathol., 48(5):447-55, 1995. 
PIDSAYA, A.; HIPKAEO, W.; KONDO, H. \& PILAKASIRI, K. Spatiotemporally differential expression of HER (human epithelial growth factor receptor)-2 with sexual dimorphism in submandibular gland of mice. Int. J. Morphol., 39(5):xxx-xxx, 2021.

Glisson, B., Colevas, A. D.; Haddad, R.; Krane, J.; El-Naggar, A.; Kies, M.; Costello, R.; Summey, C.; Arquette, M.; Langer, C.; et al. HER2 expression in salivary gland carcinomas: dependence on histological subtype. Clin. Cancer Res., 10(3):944-6, 2004.

Gresik, E. W. Postnatal developmental changes in submandibular glands of rats and mice. J. Histochem. Cytochem., 28(8):860-70, 1980.

Gresik, E. W. The granular convoluted tubule (GCT) cell ofrodent submandibular glands. Microsc. Res. Tech., 27(1):1-24, 1994.

Half, E.; Broaddus, R.; Danenberg, K. D.; Danenberg, P. V.; Ayers, G. D. \& Sinicrope, F. A. HER-2 receptor expression, localization, and activation incolorectal cencer cell line and human tumors. Int. J. Cancer, 108(4):540-8, 2004.

Herrmann, J. M. \& Spang, A. Intracellular parcel service: current issues in intracellular membrane trafficking. Methods Mol.Biol., 1270:1$12,2015$.

Hipkaeo, W.; Wakayama, T.; Yamamoto, M. \& Iseki, S. Expression and localization of the transcription factor JunD in the duct system of mouse submandibular gland. J. Histochem. Cytochem., 52(4):47990, 2004

Kamnate, A.; Sirisin, J.; Polsan, Y.; Chomphoo, S.; Watanabe, M.; Kondo, H. \& Hipkaeo, W. In situ localization of diacylglycerol lipase a and b producing an endocannabinoid 2-arachidonoylglycerol and of cannabinoid receptor 1 in the primary oocytes of postnatal mice. $J$. Anat., 238(6):1330-40, 2021.

Kapitanovic, S.; Radosevic, S.; Kapitanovic, M.; Andelinovic, S.; Ferencic, Z.; Tavassoli, M.; Primorac, D.; Sonicki, Z.; Spaventi, S.; Pavelic, K. \& Spaventi, R. The expression of p185(HER-2/neu) correlates with the stage of disease and survival in colorectal cancer. Gastroenterology, 112(4):1103-13, 1997.

Kokai, Y.; Cohen, J. A.; Drebin, J. A. \& Greene, M. I. Stage- and tissuespecific expression of the neu oncogene in rat development. Proc. Natl. Acad. Sci. U. S. A., 84(23):8498-501, 1987.

Lewis-Wambi, J. S. \& Jordan, V. C. Estrogen regulation of apoptosis: how can one hormone stimulate and inhibit? Breast Cancer Res., 11(3):206, 2009.

Liang, L.; Williams, M. D. \& Bell, D. Expression of PTEN, Expression of PTEN, Androgen Receptor, HER2/neu, Cytokeratin 5/6, Estrogen Receptor-Beta, HMGA2, and PLAG1 in Salivary Duct Carcinoma. Head Neck Pathol., 13(4):529-34, 2018.

Oshima, C. T.; Lanzoni, V. P.; Iriya, K. \& Forones, N. M. C-erbB-2 oncoprotein in gastric carcinoma: correlation with clinical stage and prognosis. Int. J. Biol. Markers, 16(4):250-4, 2001.

Press, M. F.; Cordon-Cardo, C. \& Slamon, D. J. Expression of the HER$2 /$ neu proto-oncogene in normal human adult and fetal tissues. Oncogene, 5(7):953- 62, 1990.

Quirke, P.; Pickles, A.; Tuzi, N. L.; Mohamdee, O. \& Gullick, W. J. Pattern of expression of c-erbB-2 oncoprotein in human fetuses. Br. J. Cancer, 60(1):64-9, 1989.

Rawangwong, A.; Watanabe, M.; Kondo, H. \& Hipkaeo, W. Expression and localization of endogenous phospholipase $\mathrm{Cb} 3$ confined to basal cells in situ of immature ducts and adult excretory ducts of submandibular gland of mice. Acta Histochem., 122(2):151497, 2020.

Schliwa, M.; van Blerkom, J. \& Porter, K. R. Stabilization and the cytoplasmic ground substance in detergent-opened cells and a structural and biochemical analysis of its composition. Proc. Natl. Sci. U. S. A., 78(7):4329-33, 1981.

Slamon, D. J.; Clark, G. M.; Wong, S. G.; Levin, W. J.; Ullrich, A. \& McGuire, W. L. Human breast cancer: correlation of relapse and survival with amplification of the HER-2/neu oncogene. Science, 235(4785):177-82, 1987.

Zschiesche, W.; Schönborn, I.; Minguillon, C. \& Spitzer, E. Significance of immunohistochemical c-erbB-2 product localization pattern for prognosis of primary human breast cancer. Cancer Lett., 81(1):89-94, 1994.

\author{
Corresponding author: \\ Department of Anatomy \\ Faculty of Medicine Siriraj Hospital \\ Mahidol University \\ Bangkoknoi \\ Bangkok 10700 \\ THAILAND
}

Email: kpilakasiri5@yahoo.com

Received: 21-06-2021

Accepted: 27-06-2021 